\title{
STIRRING THE POT
}

\section{(A short play in six scenes)}

\author{
Sue Donaldson
}

\begin{abstract}
SETTING
An unknown island. All of the action takes place on an outdoor terrace, with a large tree. A cord, barely visible, suspends a small bag hidden amongst the leaves of the tree. There is a table and chairs on the terrace. There is a large fire pit with a giant cauldron and spoon. Above the cauldron a harness containing HUMAN is suspended from above on a pulley system attached to an anchor point on the ground (or the tree). Nearby there is a stepladder on wheels.
\end{abstract}

\section{CHARACTERS}

HUMAN: Male, middle-aged, well fed, stripped down to this underwear

RAT: Female, confident, sexy, dressed in faux leather, carries a whip

HOUND: Male, energetic, dressed in sweats

SHEEP: Female, older, a bit fussy 


\section{SCENE 1}

(HUMAN, with bandaged head, is suspended above the cooking pot in the harness. Enter HOUND. HUMAN feigns sleep.)

HOUND: (He whispers.) Human? Human? You awake?

(HOUND reaches up and touches HUMAN gently on the foot. There is no response. HOUND looks around furtively. He rolls the ladder to the tree, climbs up and retrieves the bag by pulling up the cord. He opens it and eats hungrily from the sausages, not noticing that HUMAN has turned to look at him. HOUND stashes the food again and descends the

Human? You awake? ladder. HUMAN pretends to be asleep.)

(HOUND prods HUMAN's foot again. Enter RAT.)

RAT: What are you doing?

HOUND: He's asleep.

RAT: So?

HOUND: Shouldn't we wake him? It's time for the final test.

RAT: (She spits.) Test.

(HOUND looks at HUMAN, then gestures to RAT to step a few feet away so they won't wake him up.)

HOUND: You gonna rig it again?

RAT: Why do you care?

HOUND: Nothin.

RAT: Getting a conscience?

HOUND: No.

RAT: Well?

HOUND: I dunno. It doesn't seem right. Not... sporting.

RAT: Sporting. How quaint. He'd fail anyway.

HOUND: I know. 
RAT: So you want to run the test legit this time, now that you know he'll fail. You want a clear conscience to enjoy your first flesh meal in a month.

HOUND: Why not? Besides, if Sheep figures out it's rigged...

RAT: (She shrugs.) Makes no difference to me. He'll fail anyway.

HOUND: Exactly. But I'll feel better.

RAT: Where is Sheep?

HOUND: I dunno.

RAT: Well find her, will you? While I get the stuff for the test. Don't worry, I'll make sure it's kosher this time.

(Exit RAT and HOUND.)

\section{SCENE 2}

(HUMAN snaps awake. He rubs his hands together, then attempts to pull himself up the rope. He slips down immediately. He examines his hands.)

HUMAN: What the fuck? They've greased it!

(HUMAN wipes his hands on his shorts, and makes another attempt. He slips again.)

Fuck!

(HUMAN looks around. He starts gently swinging the harness towards the ladder. Enter SHEEP, reading a large book called "THE CODE". She looks up.)

SHEEP: What do you think you're doing?

HUMAN: Nothing.

SHEEP: I'm not blind.

HUMAN: It chafes.

SHEEP: The harness? That's top quality alligator leather.

HUMAN: Well it chafes, and I demand a replacement. Want to see my leather burns?

SHEEP: Not really. 
HUMAN: Come on. Roll that ladder over here. I demand that you climb up for an inspection. Or do you not care that you're running a torture chamber here?

SHEEP: We do not condone torture.

HUMAN: No? Come and see for yourself. My balls are crushed. I'm raw. I'm bleeding.

SHEEP: The harness is made to precise specifications. It's all laid out in THE CODE, right here.

HUMAN: Well they sure aren't human specifications. The leg holes are obviously a hatchet job. They're too wide apart.

SHEEP: We've never had a human before, so we used the porpoise harness. We improvised the leg holes.

HUMAN: Well I call it torture.

SHEEP: But torture is illegal.

HUMAN: Look...Sheep. I can see you're devoted to your laws - your CODE --whatever. But that Rat - Frankly, I can't fathom why she's been put in charge around here since you clearly possess more-

SHEEP: Who says Rat's in charge?

HUMAN: I'm only judging from the way you all seem to defer-

SHEEP: THE CODE is our authority.

HUMAN: Well I'm glad to hear that. I'm a lawyer myself, you know - you will not find a bigger fan of the rule of law. It's the basis of civilization. Which is why the matter of my harness-

SHEEP: It chafes.

HUMAN: I wouldn't fuss about a little chafing, but the compression. The lack of circulation. There's my sperm count to consider.

SHEEP: Oh.

HUMAN: If this harness were to cost me my ability to father children, you'd agree that's torture, wouldn't you? Cruel and unusual punishment, at the very least?

SHEEP: But Human, you needn't worry about fathering children. You're not going to be around that long. And we're not envisioning a breeding program. 
HUMAN: Now hold on a minute, Sheep. What about the test? What if I pass the test and you have to release me?

SHEEP: It's very unlikely you'll pass the test, Human, since you've failed every other attempt. Why do you think we've got you harnessed up and ready to go?

HUMAN: Well I call it unseemly haste. A farce. A kangaroo court.

SHEEP: Calm yourself. In the unlikely event that you should pass the test-

HUMAN: So you have to allow that I could pass the test? Theoretically speaking?

SHEEP: Well of course. Theoretically speaking. I assure you the system is not rigged, human. It's all-

HUMAN: So you say. Meanwhile it's only right to warn you, Sheep, that if I get out of this contraption, and there's any permanent damage, well, all I'm saying is you can expect to be slapped with a very nasty lawsuit.

SHEEP: Oh.

HUMAN: Years of litigation. Think of the cost. The PR damage. Something to mull over, isn't it?

SHEEP: What are you proposing?

HUMAN: I'm proposing that you roll that ladder over here to investigate for yourself. I want you to see how tight the harness is, and whether we can shift it to make me a little more comfortable. That's all. Until a replacement can be made, that is. A perfectly reasonable request.

SHEEP: I suppose. THE CODE is very clear on this point. Food animals must never be subject to gratuitous cruelty.

(SHEEP puts THE CODE on the table, reaches for the ladder, and starts wheeling it towards HUMAN.)

HUMAN: Good. That's good. Keep it coming, baby. (HUMAN tries to reach for the ladder.)

SHEEP: No reaching. I'll climb up to investigate your injuries, but only if you promise to keep your hands to yourself.

HUMAN: Just trying to help.

(SHEEP wheels the ladder into place. Starts to climb. Enter RAT carrying a whip.) 
RAT: What the hell's going on here?

(HUMAN makes a desperate lunge for the ladder. RAT cracks her whip and pulls the ladder away.)

Sheep? Talk to me, Sheep. What the hell are you doing?

SHEEP: There's no need for that tone. His harness is chafing.

RAT: Chafing? Are you kidding?

SHEEP: I was just going to investigate. His uh, his manhood is being squashed.

RAT: (She laughs.) You idiot, Sheep. You fell for that? Lucky I came when I did. A moment later and I'd have found you on the ground with your brains bah bah bashed in.

SHEEP \& HUMAN: No-

RAT: Yes.

SHEEP: You always think the worst of -

HUMAN: That's right. Don't listen to her, Sheep. She-

RAT: Shut up, Human! Where's Hound? Can we do the god damn test? I'm starving. Go find him.

(Exit SHEEP. RAT circles HUMAN. She snaps her whip towards his crotch.)

HUMAN: Easy there.

RAT: The harness is too tight? Worried about your circulation? I can stir things up there a little, if that's what you want.

HUMAN: Pervert.

RAT: (She laughs.) Pouting, are we? Did I foil the Human's little escape ploy?

HUMAN: You mis-

RAT: Tell me, human. What was your plan after tossing Sheep off the ladder? You can't get out of the harness. Believe me, many have tried.

HUMAN: Ahh, shall we put it to the test? Ever heard of the miracle of opposable thumbs, Rat?

RAT: (She laughs.) So you admit you were trying to escape? 
HUMAN: No point trying to pull the wool over your eyes.

RAT: Touché, human.

\section{SCENE 3}

(Enter HOUND carrying a basket of potatoes.)

HOUND: Isn't it time for the test?

RAT: Where's Sheep?

HOUND: I dunno.

RAT: What a bloody farce. She went looking for you, idiot.

HOUND: Well I haven't seen her. And I don't like your tone.

RAT: Yeah, well, I'm sorry, Hound. It's just I'm bloody sick of sprouts.

HOUND: Me too.

HUMAN: Me too.

RAT: Nobody asked you. (TO HOUND) Sheep doesn't seem to mind.

HOUND: The herbivore advantage. (Pause.) Actually, Rat, there's something-

RAT: Did you bring the stuff for the test? Let's just run the bloody test.

HOUND: I thought you were getting the stuff.

RAT: Yeah... well, and I thought you were getting Sheep. Jesus. If she returns, tie her down.

(Exit RAT. HOUND sits down at the table and begins to peel potatoes from the basket.)

HOUND: So tell me, Human-

HUMAN: Why don't you tell her?

HOUND: Tell who? Tell her what?

HUMAN: Rat. 
HOUND: What?

HUMAN: Your little secret.

HOUND: What secret?

HUMAN: Give me a little credit, will you?

HOUND: I don't see-

(Enter SHEEP, carrying a tray.)

Shut up. (To Sheep) Where were you?

SHEEP: Where were you? And where's Rat?

HOUND: Getting the test items. Whatcha got there?

SHEEP: Garlic, fennel.

HUMAN: Fennel? I love fennel.

SHEEP: Mmmm. Me too. Might as well begin chopping. (She starts chopping at the table.)

HOUND: Rat's in some kind of a mood, by the way. So look out.

SHEEP: Oh?

HOUND: Just hungry, I guess.

HUMAN: Why do you care?

HOUND: What's that, human?

HUMAN: Why do you all pander to that erratic and tyrannical Rat? Why all the trouble to placate her so?

HOUND: My my. "Pander" "Placate." Isn't our Human learned! Aren't you impressed, Sheep? Now I see why he carries that pocket lexicon around.

HUMAN: Pocket lexicon? Have you got my Blackberry?

HOUND: The Human's losing it.

SHEEP: No blackberries, Human. Just fennel and garlic. (To HOUND) I think his harness is too tight. 
HUMAN: Is it her whip? Is that what scares you?

HOUND: What's your point, Human?

HUMAN: Don't you long to be free?

HOUND: You're projecting.

HUMAN: You let her drag you around by the snout.

HOUND: I do not-

HUMAN: I'd never let her boss me around like-

HOUND: (He laughs.) Stupid Human. Rat's got you right where she wants you - all trussed and ready to go. A pound of your juicy flesh is all the cure any of us needs. White meat, preferably.

HUMAN: Ahh, so you're hungry too, Hound? But I notice you're not quite as skinny-

HOUND: The Human hallucinates. Did you say his harness is too tight?

HUMAN: You're damn right it's too tight. It's chafing-

SHEEP: Oh no. Here we go again.

\section{SCENE 4}

(Enter RAT, carrying three tin foil packages, each about the size of a potato.)

RAT: Here we go again, indeed. Ready, Human?

(RAT picks up a tin-foil package, then puts it down again. She picks up another package and walks towards HUMAN.)

It's your last chance. You ready?

HUMAN: Whatever.

RAT: What's your problem?

HUMAN: All kosher this time, is it?

RAT: (She laughs.) By the book, Human. Just ask Sheep, here. 
HUMAN: Right.

(RAT pushes the ladder over to the pot. She climbs up, then turns to SHEEP and HOUND.)

RAT: You guys ready?

HOUND: Yep.

SHEEP: Proceed.

(RAT holds a tin-foil package under HUMAN's nose.)

RAT: Okay Human. What is it?

(HUMAN sniffs loudly, and leans towards the package.)

HUMAN: Come a little closer.

(HUMAN lunges for the package. RAT snatches it away.)

RAT: Naughty Human. No touching.

(RAT reaches the package up under HUMAN's nose. HUMAN sniffs again.)

HUMAN: Is it the apple?

RAT: (Cracks her whip.) No. It is not the apple. No, no, and no! He's wrong again!

HOUND: Geez he's bad.

(RAT unwraps the package and holds up a beet.)

RAT: See? It's the beet. That's conclusive, folks. This human does not smell.

HUMAN: I do smell!

RAT: Oh, human. You may stink, to paraphrase dear old Dr. Johnson, but you do not smell.

HUMAN: You haven't let me bathe.

RAT: Who needs to bathe? Do we stink? None of us bathes.

HUMAN: And even if I can't smell so well as-

RAT: Enough! We've run the test, friends, and this human can't smell worth a damn. I say we eat him.

(RAT dismounts, and gives the pot a stir. HOUND picks up a potato and tosses it hand to hand.) 
HOUND: Poor fellow. I bet he doesn't even know his own piss, for christsake - never mind anyone else's. Can you imagine? Walking down a street with no clue who's been by?

SHEEP: Better to be deaf, to be blind... But to lack smell!

HUMAN: I can smell!

(SHEEP sits down and continues chopping fennel. RAT holds up a beet.)

RAT: You call that a sense of smell? You can't distinguish an apple from a beet!

(RAT tosses the beet back onto the table with the other two packages.)

HOUND: I dunno. I feel kinda sorry for him. He can't help it, I guess.

(HOUND tosses the potato into the pot.)

SHEEP: Your sympathy does you credit, Hound, but he has failed the test, the gold standard-

HUMAN: This is ridiculous.

RAT: Shut up. We've run the test five times, Hound, and he's 0 for 5. Even on straight odds he should have done better than that. The flounders did better, and we eat them all the time. Sheep, read that passage again, will you? The test specifications.

(SHEEP puts on her glasses, opens the CODE, and takes time finding the correct passage while RAT paces, till HOUND tosses a potato at her. RAT flings it back.)

SHEEP: I quote: "The subject creature shall correctly distinguish three food items wrapped in tin foil when held directly under his or her nose. The items for detection should be of an olfactory magnitude equivalent to that which a rat is capable of distinguishing at 20 metres, and not more than 22 metres. Henceforth to be called the Rat-20 test."

RAT: (Cracking her whip.) Exactly. We followed those specifications to a " $t$ ". And he failed -all five times.

HOUND: But was it okay to use the same items each time? (Juggles a potato.) Like, maybe he has a disability relating just to beets, or apples. Shouldn't we test him on some different ones?

(HOUND tosses the potato to HUMAN.)

HUMAN: You'd make a good lawyer, Hound.

RAT: Hound, What the hell's going-

SHEEP: Wait. There is an addendum here: "If the test results are in doubt, it is admissible to run the test again using a different series of items of the same olfactory magnitude."

(RAT grabs THE CODE, snaps it shut, and slams it on the table.) 
RAT: There was no doubt! He wasn't even close!

HUMAN: Wasn't I?

RAT: What?

HUMAN: You have no idea whether I was close or not, because you rigged the test.

SHEEP: Rigged the test?

RAT: Liar!

SHEEP: This is a serious charge, Human. I hope you can back it up.

HUMAN: Even better, I have a witness. (Tosses potato in the pot.)

RAT: Shut up, human.

HUMAN: Don't I, Hound?

HOUND: I don't know what you're talking about.

SHEEP: Hound? What do you know about this?

(Pause. HOUND picks up another potato and starts tossing. HUMAN gazes pointedly towards HOUND's secret food stash.)

Stop fidgeting and tell me what you know.

HOUND: Rat rigged the first four tests. But not this last one. It was legit.

RAT: I rigged the tests? We rigged the tests, you cowardly-

SHEEP: You admit it?

RAT: Who cares? We've just run the test again, and he's failed fair and square. It's perfectly obvious he can't smell.

SHEEP: But you've put the entire proceedings under a dark cloud.

HUMAN: Collusion. Corruption. What does THE CODE say about them apples, eh Sheep? Or is it beets?

SHEEP: How can we enjoy a Human stew if the process isn't above reproach? Ethical meat. For generations-

RAT: Spare us. 
HUMAN: It's as we discussed earlier, Sheep, about the legal niceties.

HOUND: Now wait-

RAT: (She laughs.) Human, you really are too much. Sheep, before you champion this blackguard, it may interest you to know what he confessed to me a while back about his plan to throw you off the ladder, then use his opposable thumbs to escape the harness. He chose you, you see, because he figured he could pull the wool over your eyes. Forgive me, those are his words. You don't believe me, I see, but did he not tell you that the harness was chafing? That he was sore and bleeding and required you to check him out? Well climb up and have a look for yourself. Go on. See whether he's oozing blood.

SHEEP: I don't believe-

HOUND: Well I'll check it out. (To HUMAN) Were you really planning to hurt our Sheep? (HOUND rolls ladder over and starts to climb up for a look. HUMAN waves him away.)

HUMAN: Forget it. Point to you, Rat.

(RAT takes a little bow, as HOUND climbs down and resumes his seat at the table.)

Nevertheless, you've admitted to rigging the test. I demand my freedom.

RAT: (She laughs.) I like your spirit, Human, but you're in no position to be making demands. THE CODE requires only one test. We went above and beyond-

SHEEP: (Placing her hand on THE CODE.) Excuse me, Rat, but I believe the decision should fall to me. Notwithstanding this human's despicable behaviour, justice must be seen to be done. And I, for one, cannot permit personal offense to influence my judgment. I say we test him one more time, with new items, and I'll make sure there are no irregularities. But this will be his last opportunity. (Resumes chopping the vegetables.)

HOUND: It's agreed, then? We'll test him one more time with different items?

(HOUND looks at RAT, who shrugs. HOUND juggles the potato.)

HUMAN: Yes, please change the items. May I propose a rotten egg, sauerkraut, and a warm cinnamon cobbler?

(The animals laugh. HOUND tosses potato to HUMAN.)

HOUND: He has a sense of humour. You have to give him that.

(HUMAN smiles. He tosses the potato into the pot.)

RAT: Sure he has a sense of humour. He has opposable thumbs, too. And he's bipedal, nonflying, and can't breathe under water. Who cares? None of these points is relevant. Sense of smell. That's the test. 
HOUND: No argument here.

HUMAN: Who cares about smell? I can talk. I can reason. Where I come from that's what counts.

RAT: Everybody can talk and reason. If that were the test there'd be nothing left to eat!

HUMAN: Well in my world it's only we humans who talk, or engage in extended rational analysis-

RAT: Yeah. Yeah. Forget your world, Human. You washed up in our world, remember? And we do things differently around here. (Pause.) Let me ask you a question, Human. Have you ever had a really bad cold—nose and sinuses completely stuffed up?

HUMAN: Of course.

RAT: And did you enjoy your meals at the time? Savour the flavours, and all that?

HUMAN: I don't remember having much appetite. Couldn't really taste anything.

RAT: Exactly. The nose is stuffed. No smell, and therefore taste is impaired. Agreed?

HUMAN: I suppose.

RAT: So you agree that smell is related to taste and enjoyment of food? (RAT picks up a potato.)

HUMAN: I.....guess....

RAT: So we're agreed that an individual's appreciation of food is related to a functioning sense of smell. Does it not follow, therefore, that a species with a more advanced sense of smell will have a greater food appreciation than a species with a more limited sense of smell?

(RAT lobs the potato to HOUND. He nods, and lobs it back.)

HUMAN: Well...now-

RAT: Obviously the sense of smell is the key sense when it comes to preparing and appreciating food. And obviously we maximize the good by eating those who can't smell very well, while allowing more refined creatures to enjoy a rich banquet on which to exercise our discriminating palates! What could be more rational than that? (Tosses potato in the pot.)

HUMAN: Wait a minute. I-

RAT: But I thought you were a big fan of reason, human. Wasn't that a tidy piece of reasoning? 
HOUND: I'll say. A logical tour de force. Well spoken, Rat.

SHEEP: Bravo. I smell. Ergo sum. It's the opening line of our great CODE.

RAT: Quite so. Reason has its place, Human, but when it comes to the great chain of culinary being, smell is supreme.

HOUND \& SHEEP: Smell is supreme! Smell is supreme!

RAT: Our greatest gourmands have rarely been geniuses. Take Sheep, here. No offense, Sheep, but you're not exactly the sharpest knife in the drawer. Yet when it comes to sniffing out the choicest herbs for a sauce ravigote, Sheep, here, is without peer. Sense of smell. That's the key. Not reason. You want bright? How about the porpoises? They're plenty bright. But they can't smell worth a damn. And we eat them all the time. Smoked porpoise. It's a great delicacy. (RAT cracks her whip.)

HOUND: Agreed. Smell is the issue here. If we start to question that, we throw into doubt our entire history, all of our traditions. (Picks up a potato, juggles it.)

SHEEP: THE CODE is eloquent on this point. "The discriminating shall eat, the indiscriminate shall be meat!" I know that passage by heart. The "indiscriminate" includes the fishes, the birds, excluding the carrion eaters, of course, most of the amphibians and a few of the lesser mammals, of which this human seems to be one.

HUMAN: Lesser mammals! But I'm at the top of the chain. You've got it all backwards. We humans excel using our brains, not our... hairy wet snouts.

HOUND: Are you being insulting?

HUMAN: Okay. Calm now. Let's all calm down. I'm not insulting you, or the folks who wrote your CODE, but obviously they never encountered a human or they would have realized the inadequacy of this ridiculous test. Morally speaking, it's completely arbitrary, don't you see? You might as well test my...my potato-toss skills.

SHEEP: While it is true the catalogue does not specifically speak of humans, the framers of our great CODE were very wise creatures indeed. They foresaw a day when you would wash ashore; and hence, the clause pertaining to residual beasts not present at the genesis. (Reads.) I quote: "Residual beasts not encompassed by the current catalogue will submit to the olfactory test, and be inserted into the catalogue accordingly."

HUMAN: Hold it! Hold on just a minute. You said beasts, residual beasts. But I am not a beast! I'm a human being!

RAT: You are a beast! And a Jesuitical one at that! 
HUMAN: No! No. Hear me out. (He turns to HOUND.) Where's my pocket lexicon?

(HOUND tosses the potato to HUMAN, then pulls the Blackberry from his back pocket and holds it up.)

Now, look up "beast," will you? What does it say?

HOUND: (Reads.) “Any animal except man; especially, any large quadruped.”

HUMAN: Exactly! I am a man. Ergo I am not a beast! (Tosses potato in the pot.)

SHEEP: I believe our lexicon defines beasts as all living animals.

HUMAN: That's because you've never had humans-not until now. As you noted, Sheep, the framers of your great CODE used the word "beast" quite deliberately. Don't you see? They did foresee the day humans would arrive here, and clearly their intent was that we humans should not submit to the olfactory test.

RAT: Hound, give me the lexicon. (She reads silently). Wait a minute. Wait a minute. I have a question for you, human. What is a "person"?

HUMAN: A person? Well, let's see. That's any individual human being. There's some question about when personhood is established -- at conception? At birth? That kind of thing. And, oh yes, let me see.... for legal purposes a corporation can sometimes have the status of person. So, for example-

RAT: Never mind that. You agree that human beings are persons?

HUMAN: Yes.

RAT: Well then, I draw your attention once again to the definition of beast. Hound simply stopped reading too soon. Beast: Definition 1: "Any animal except man; especially, any large quadruped.” Definition 2: blah blah blah. Irrelevant...Here we are! Definition 3: Beast: "A cruel, rude or filthy person." Now you agreed, human, that human beings are persons. And according to this definition, a person can be a beast. Therefore humans are beasts! If $\mathrm{A}=\mathrm{B}$ and $\mathrm{B}=\mathrm{C}$, then $\mathrm{A}=\mathrm{C}$. We call that a syllogism, human-but I guess you know that, being a big fan of reason and all. The point is, I have demonstrated that you are indeed a beast.

(RAT mounts the ladder, and hands the Blackberry to HUMAN indicating the passage. HUMAN reads silently. SHEEP pauses chopping, looking puzzled. She draws an equation in the air with her knife.)

SHEEP: If $\mathrm{A}=\mathrm{B}$ and $\mathrm{B}=$

HUMAN: But this is a metaphorical use. Don't you see? It's meant as an insult. When you call a person a beast it stings precisely because we humans are not beasts. If you say to me "you're a beast" it's like saying "you're behaving like an animal." If I were actually a beast, there'd be no sting, no insult. You must see that! 
RAT: (Grabs Blackberry and dismounts.) I didn't read anything there about metaphors or figures of speech. Sorry Human. Hoist on your own petard, as we say. (To HOUND and SHEEP.) I propose we test him one more time, my friends, and get on with it. I'm starving. What are you chopping there Sheep?

HUMAN: Can't you smell it?

RAT: No need to be sarcastic, human. We call such inquiries "making polite conversation."

SHEEP: I'm chopping fennel, and a little -garlic-for the sauce, of course.

RAT: You were thinking a rouille, perhaps? Or something stronger? Romesco?

SHEEP: How is our stock of chillies?

HOUND: Are you thinking mole? I love a good mole sauce. (Picks up a potato and juggles.)

SHEEP: No chocolate for you, Hound.

RAT: I don't know. He might be better minced, no? In a ragu—with lots of onion. He's a real stinker. And a trifle bitter, too, would be my guess.

HUMAN: If I may interrupt these gastronomic fantasies for a moment, are you at least going to let me take the test again before turning me into a ragu?

HOUND: We did agree to another test. (Tosses the potato to HUMAN.)

RAT: Yes. We agreed. So let's get it over with.

HUMAN: You're agreed, then? I get another test?

RAT: What part of "yes" do you not understand?

HOUND: We are all agreed. I'll get-

HUMAN: Wait. Wait. Not so fast. You may have no respect for the human nose, but I assure you it is a very delicate instrument, and that garlic has contaminated the environment here. You'll have to delay-

RAT: Why, you-

HOUND: Easy, Rat.

HUMAN: All fair and square. You promised, this time. (Tosses potato into pot.) 
SHEEP: Let us consult THE CODE. I believe there is a paragraph, therein, sub-section to the olfactory test law, pertaining to procedural matters.

RAT: (She laughs.) Enjoying yourself, Human?

HUMAN: You may think this is a game-

RAT: 'Cause I can be patient. There's more than one way to savour a stew, Human. Sheep, you can consult THE CODE later. First get that garlic out of here so we can "de-contaminate" the environment for this picky human. Keep an eye on him, Hound. I'll collect three more food samples for the test.

(Exit SHEEP, carrying cutting board with garlic and fennel. Exit RAT, carrying the 3 tin-foil packages.)

\section{SCENE 5}

(HOUND sits down on bench and watches HUMAN who is swinging in his harness, testing whether he can reach the ladder. HOUND starts juggling a potato.)

HUMAN: Have pity, Hound. Get me out of this damn contraption. I promise never to show my face around here again. I could even rough you up a bit, just to make it look good. They'd never suspect a thing.

HOUND: Why should I help you? (Tosses the potato to HUMAN.)

HUMAN: Why should you harm me? Have I ever harmed you? (Tosses the potato back.)

HOUND: No, and I wouldn't dream of harming you, either. We take our animal welfare quite seriously here, you know. We've fed you, haven't we? Watered you? Housed you? Take that harness, it's wonderfully supple, isn't it? You can admit that, now.

HUMAN: But you're going to kill me! Who cares about the stupid harness?

HOUND: (Juggling potato.) To be honest, human, I can't see much value in a life without smell. Brute, mute misery if you ask me. You could call it an act of mercy, ending such an existence.

Non-existence, really. If my sense of smell were as crippled as yours, I'd jump into that pot right along with ya, buddy. (Takes a jump shot, tossing potato into pot.) And between you and me, it's nothing to do with THE CODE. I don't care what THE CODE says - the discriminating shall eat meat, all that stuff. I'm just talking about being alive, man. Truly alive, in this everyday world. Without smell, it's nothing. All the good stuff-sex, a walk in the woods, a fine meal - it might as well be sawdust. (Picks up another potato.) 
HUMAN: But it's not like that at all. We compensate. We're more visual, more cerebral. Believe me, it's a good life. And a damn sight better that being stewed in a pot! Of all the cruel-

HOUND: Cruel? I don't think so, human. THE CODE's quite explicit on the matter of humane slaughter. We can ask Sheep to read that passage if it'll make ya feel better. Believe me, we'll have that water boiling so fast you'll be dead the moment you splash down... or pretty much, anyway. So there's no need to worry about that. We'll make it as painless as possible.

HUMAN: But I don't want to die! Can't you see that? I don't want a humane death. I don't want any death. And how can you call this humane, anyway? Suspending me over this kettle of death and forcing me to pass ludicrous olfactory tests to save my life?

HOUND: Now you're being hysterical. I'm going to see what's keeping the others.

HUMAN: No. Hound. Wait a moment. Just wait. Please? I was hoping that you...that I could talk to you. You're not like the others. You see, in my world your kind and mine have a special bond. In fact I have a pet-I I mean a companion just like you. His name is Rex. Hey, hand me my lexicon, will you?

HOUND: (Passes up Blackberry.) Why?

HUMAN: Look at this. "Rex". See? It means King.

HOUND: King! Gee, I like the sound of that. In your world dogs are King?

HUMAN: You bet they are. And humans are a dog's best friend. Rex and I do all kinds of stuff together-walking, playing frisbee, hunting...

HOUND: Hunting? Whadya hunt? (Tosses the potato to HUMAN.)

HUMAN: Ducks, deer. (Tosses the potato back.)

HOUND: Gee, we're not allowed to hunt deer here - they're olfactorily advanced. (Tosses the potato back to HUMAN.)

HUMAN: We also....hunted.... rats.

HOUND: Rats?

HUMAN: Where I come from rats are the lowest of the low. Vermin, we call them.

HOUND: Vermin! I don't like the sound of that. I think you'd better- 
HUMAN: Stop thinking with your dick for a moment. She's just a rat for christsakes. And I have to say I'm pretty shocked by the way you all defer to her. Take that olfactory test. The Rat-20 test. What is that? Why are rats the standard of excellence? I thought you bloodhounds were geniuses in the olfactory department. So why isn't the test pegged to a hound standard? (Tosses the potato into the pot.)

HOUND: Yeah, well, I'm sure there's a reasonable explanation... But you're right, we hounds are masters in the detection department. You know, I can detect a ready female at-- Geez! Human! Without smell, how do ya know when your females are, ya know... ready... ready to do it?

HUMAN: (He laughs.) Oh, no great mystery there. We ask them. And there's body language, of course.

HOUND: You mean, you have to be within aural or visual range? What if she's several blocks away? You could miss a lot of chances...

HUMAN: Nah. We've also got cell phones.

HOUND: And what about interlopers? How do you know when someone's been trespassing in your zone if you can't pick up their scent?

HUMAN: We've got security cameras for that.

HOUND: I see. So, like, basically, you've got a bunch of techno fixes to compensate for your natural deficits?

HUMAN: I wouldn't put it like_— Listen! Did you hear something?

HOUND: Sure, the others are returning.

HUMAN: Quick. Get me out of this thing.

HOUND: I don't think I can do that, Human. I need to think it over.

HUMAN: No time. Listen, Hound. Either you get me out of here, or I spill the beans. I know all about your little food stash, okay? So if you want to keep your little secret, then get that ladder over here.

(HOUND looks from HUMAN to the food stash and back. Grabs the ladder and starts wheeling it towards HUMAN.) 


\section{SCENE 6}

(Enter SHEEP and RAT, carrying three tin foil packages. HOUND pauses.)

HUMAN: Shit.

RAT: What's going on here?

HOUND: Nothing.

RAT: Well keep that ladder away from him, will you?

SHEEP: The garlic is safely removed from olfactory range.

RAT: It's chilly here. Stir up the fire, Hound. I think the environment is sufficiently decontaminated for our picky human.

HOUND: Stir it yourself. Who died and made you king?

RAT: Ouch. Hound. Who loves you, baby? Human been filling your ears with poison?

HOUND: He was just telling me a little about life in his world -- where dogs are kings and humans are their hunting assistants. (Juggles a potato.)

RAT: Is that right? Hunting, you say? And what do you dogs and humans hunt together, pray tell?

HOUND: Uh... ducks?

RAT: Human, give me that lexicon again. (RAT mounts the ladder.) Let me see your pocket lexicon. (Reaches for the Blackberry. HUMAN grabs it back.)

HUMAN: Hold on a minute. First I have a question. A protest, really. I wish to lodge a protest. It's about that syllogism of yours, Rat. You claim that I am a beast because of the third definition of "beast," which is... (He reads.) "a cruel, rude or filthy person." Now you constructed the syllogism as follows: A human is a person. A person is a beast. Therefore a human is a beast. But your second premise is incorrect. Not every person is a beast. Only a cruel, rude, or filthy person is a beast. So it does not follow that I am a beast!

RAT: Let me see that! (Reads silently.) Ahhh human, clever human. Not ready to concede, yet, eh? That's okay. I'm enjoying our little sport. And perhaps my logic was a tad hasty. We must be above reproach, eh? Dot our "i $i$ "s and cross our "t"s, as Sheep likes to say. 
SHEEP: Cruel, rude or filthy person? Is that how his lexicon defines "beast"?

RAT: Indeed.

SHEEP: I say he stinks. Hound?

HOUND: I'd have to agree. He stinks.

(HUMAN looks pointedly at HOUND, who shrugs.)

RAT: So he's filthy. And he is certainly rude. Did you see him snatch that lexicon from me just now? Not to mention the interrupting.

(RAT dismounts while speaking, placing the Blackberry on the bench.)

SHEEP: And the sarcastic remarks.

HUMAN: But I'm not cruel. I am not cruel!

RAT: Ahh, but now it's your logic that is faulty, human. The definition says cruel, rude OR filthy. Not cruel, rude AND filthy. We find you to be filthy and rude. Two out of three is more than enough to define you as a beast. Any one would be sufficient.

HUMAN: But "cruel" is the primary definition. And the structure is ambiguous. The "OR" structure could mean that one has to be "cruel" and "rude," OR "cruel" and "filthy." Either way "cruel" must be part of the definition.

SHEEP: (Rubbing her eyes.) I'm getting a headache. And I begin to doubt whether the framers of our great CODE really did anticipate the arrival of this tiresome creature. Can we please give him the test and be done? I'm hungry. What new foodstuffs have you brought for the test, Rat?

RAT: A dry piece of bagel, a chunk of parmesan, and a parsnip. We can save the latter for the ragu, yes? I checked the pantry. We also have turnip, plenty of carrots, fresh sage, tarragon...

SHEEP: And we still have that bottle of cooking sherry.

RAT: Well then! The ingredients of a tasty meal are at hand!

HUMAN: Wait a minute. You can't run the test yet. You haven't answered my last point. You have failed to prove that I am a cruel person, and therefore you have failed to prove I am a beast subject to the olfactory test.

HOUND: The human has a point. (Tosses a potato to HUMAN.) We haven't demonstrated his cruelty, which means maybe he's not a beast, and so it wouldn't be fair to subject him to the test. Yes, he may stink. Yes, he may be rude. His senses may be feeble. But he hasn't harmed us, has he? Perhaps we should let him- 
RAT: Enough. I don't know what's got into you, Hound, but I grow weary of this interminable debate. Do you really doubt whether this human is cruel? Is that what we're hung up on here? What about the foiled attack on Sheep? Here, let me see that stupid lexicon. (RAT picks up the Blackberry.)

HUMAN: You can't deduce anything about my character from that lexicon. (Tosses the potato back to HOUND.)

RAT: We'll just see about that, shall we? Hound, am I right - you believe that in the human world dogs are kings, yes? Let us see here. We'll just look up "Hound" ... Here it is: Definition 1: "A dog of any of several breeds kept - kept - for hunting, especially one that hunts by scent and in a pack." That's interesting, the use of the word "kept" there. Are you sure dogs are kings, Hound? I've never heard of a "kept" king...have you? I've heard of a "kept" slave mind you... Shall we read further?... Oh, look what we have here. Definition 3: "Hound: A mean, detestable man." Hmm... Now that's very interesting. Tell us, human, could this be one of those metaphors you were talking about? Where you humans insult one another using animal epithets, a hound, say, to convey the idea of "mean" and "detestable"?

HUMAN: I would never use the word that way!

(HUMAN reaches out his arms for a pass. HOUND tucks the potato under his arm. He picks up the Blackberry and reads silently.)

SHEEP: What does his lexicon say about sheep?

HOUND: "Sheep: A medium-sized, domesticated, even-toed ruminant, bred in many varieties for its flesh, wool, and skin."

(HOUND puts the Blackberry down and starts juggling the potato.)

SHEEP: Bred for its flesh? You eat my kind? That's awful.

HUMAN: I was never very fond of lamb or mutton myself. Even with mint sauce it was much too strong a taste for me. Honest, I think I tasted it maybe once and spat it out immediately. Disgusting! And I'm allergic to wool.

SHEEP: You eat my kind?

HUMAN: Mais je suis vegetarian dans l'âme!

RAT: Hound, won't you please read the entry for "rat"?

(HOUND tosses the potato to Rat, and picks up the Blackberry again. RAT juggles the potato while HOUND reads.)

HOUND: Rat definition 1) "a destructive and injurious rodent, carrier of bubonic plague and endemic typhus." Definition 2) "Slang: A cowardly or selfish person who deserts or betrays his associates." 
HUMAN: Personally, I like rats. These definitions have nothing to do with me.

RAT: The pocket lexicon was your idea, Human. (Tosses the potato to HOUND.)

HOUND: He called rats vermin when we were alone.

(HOUND tosses the potato back to RAT. SHEEP unfastens one coil of rope suspending the harness.)

HUMAN: Forgetting something, Hound? Our little bargain? (Points towards tree.)

SHEEP: What bargain?

HOUND: Don't listen to him. He'll say anything.

RAT: What are you pointing at?

HUMAN: Just rubbing my nose, Rat. Do I need permission?

HOUND: He's hallucinating again. Let's finish this.

HUMAN: You must have noticed, ladies, how Hound here continues to fill out his clothes despite your food shortage?

HOUND: I have big bones.

SHEEP: I put it down to genes.

HUMAN: Genes, right. Ever seen a fat person in a concentration camp, Sheep?

RAT: Enough. You're offensive, Human. Stop wasting-

HUMAN: Indulge me, Rat. This won't take a moment. Roll the ladder over to the tree, there, and I'll show-

HOUND: No.

RAT: No?

HOUND: Time's up human. (HOUND reaches for the suspension rope.)

HUMAN: Hound has a secret cache of food.

RAT: (Cracking her whip at HOUND.) Hold up, Hound. This sounds interesting. Explain yourself, Human. 
HUMAN: I told you. Go over to the tree. His cache is suspended from that cord. See? It didn't have to be this way, Hound.

HOUND: He's lying.

RAT: Sheep, go and look.

(SHEEP rolls the ladder to the tree. RAT and HOUND circle warily.)

HUMAN: I saw him gorging himself. He thought I was asleep.

(SHEEP holds up the food cache.)

HOUND: I was going to tell you, Rat.

RAT: Tell me?

HOUND: About the food. I found some sausages.

(SHEEP opens the bag and holds up a sausage.)

RAT: And just when were you planning to tell me, Hound? After eating the lion's share yourself?

HOUND: I tried-

RAT: You knew how I was suffering, my guts burning and gnawing themselves raw.

HOUND: I was just waiting till we could be alone.

RAT: Alone? Oh I get it. You thought you could buy me. With a piece of meat?

HOUND: You make it sound-

RAT: Pathetic. Because it is pathetic.

HOUND: Pathetic? Look who's pathetic. You don't see me waltzing around with that ridiculous whip, lording it over my fellow creatures. You think you're too good for us? For me? Well-

RAT: I've never pretended to be a saint. And I've never betrayed my fellow creatures, either. But you. You agree to plead his case so he won't betray your little food hoard. What an act! Pretending to be oh so compassionate. Give the poor human a sporting chance. Easy for you to say. With your secret stash of meat.

HOUND: Like you wouldn't have done exactly-

SHEEP: Enough! Stop. This must stop at once. Don't you see? 
HUMAN: No. You tell her, Hound. Take charge.

HOUND: (To SHEEP.) See what?

SHEEP: THE CODE. It speaks of our great general, Sun Tzu, remember? And his strategy of divide and conquer. This human sows dissension amongst us. He seeks to turn us one against the other... (Pause.)

HOUND: Sheep is right.

RAT: Sheep is right. Thank you, Sheep. (RAT smiles at HUMAN.) Congratulations, Human. HUMAN: Congratulations?

RAT: Your Machiavellian strategy. It almost worked.

HUMAN: You're just going to suck it up? Hound's betrayal? Aren't you-

RAT: Be quiet, Human. It's really none of your affair.

HUMAN: But you've got some meat now - Hound's stash. Why do you-

RAT: Are we ready, my friends?

HOUND \& SHEEP: Ready.

HUMAN: No. No. Wait! The test. You promised me another chance at the test.

RAT: I don't think we need to waste any more time with the olfactory test. Do you Hound? (HOUND shakes his head.) Sheep?

(SHEEP shakes her head. RAT juggles the potato for a moment, looking at HUMAN, then tosses the potato into the pot.)

HUMAN: Fine, forget the test. It's stupid anyway. Don't you see that it doesn't matter? The question isn't: Can I smell? It's not even: Am I cruel and manipulative? The question is: Do I suffer? I'm appealing to your higher natures, here. We humans are base creatures, I admit it. But where is your pity? Your compassion? Surely you aspire to be better than us?

HOUND: Silence, Human. Preserve what little dignity you have left.

(RAT unfastens another coil of the rope. HOUND stirs the pot.)

HUMAN: Please. I beseech you. I don't want to boil to death. I want to live! Can't you feel my pain? 
RAT: (Pause.) Ahhh, we call that the problem of other minds, human. You say you suffer, that you have a will to live. But how can I really empathize? How can I know for sure that what you mean by these things - like suffering - is the same as what I mean? Take colour, for instance. What colour is this? (Holds up one of the tinfoil packages.)

HUMAN: Silver?

RAT: And so say I. By convention, we both call it silver. But what we can't know is if silver really looks the same to you as it does to me. Understand? Your silver might be my red, and vice versa. It's the same with suffering. You can scream, and writhe around and cry for mercy. But I don't know what you're really feeling. Your acute suffering might be my prick of a pin. Or, you may simply be a very sophisticated machine, a fancy clock that makes suffering-like noises. Computers make funny noises. Computers talk. And they're just machines. It's that old Cartesian problem. Don't you see?

HUMAN: For pity's sake! I'm a living, breathing, creature. Surely you don't need philosophy to see that. Hound? Sheep?

HOUND: You enslave us.

SHEEP: You eat us.

RAT: You exterminate us.

HUMAN: But if you prick me do I not bleed?

RAT: If you didn't bleed, you wouldn't make a very tasty ragu, now, would you?

(SHEEP releases the penultimate coil of rope. HOUND steps back from pot.)

HUMAN: No! I beg you! I-

(RAT gestures with a slicing motion across her throat. SHEEP releases the rope, and the lights go out at same moment. HUMAN screams. Splash! Sizzle!)

\section{END OF PLAY*}

*With thanks to Will Kymlicka, Christine Overall, and Joseph Salvoni for helpful suggestions. 